\title{
Growing Up In Taiwan: Cultural Adjustment And Challenges For Children Of Foreign Brides
}

Pei-Chun Liao, University of Pennsylvania, USA

Ya-huei Wang, Chung-Shan Medical University, Taiwan

\begin{abstract}
In 2010, there were over 400,000 immigrants residing in Taiwan, many of them women from Mainland China and Southeast Asia who had married a Taiwanese citizen. As a result, there has been a population boom in children of mixed nationality, and this has changed the cultural structure of Taiwan. Both non-Taiwanese residents and the children of immigrants face culture estrangement and alienation. The dominant Taiwanese ethnic group tries to impose their rules on other ethnic groups, which may result in an abuse of power that may then cause enduring pain to minority groups. This study considers the importance of culture in the lives of children of foreign brides. These children have to face individual, family, school, and societal factors that can impede their education and sense of self. In order to understand the challenges that these children may experience, this study illustrates risk factors for these children, and considers how educators can help alleviate ethnic tension and provide ethnic-related interventions to children from diverse populations.
\end{abstract}

Keywords: New Immigrant Residents; Cultural Adjustment, and Ethnic Identity

\section{INTRODUCTION}

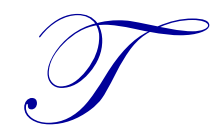

raditional Taiwanese culture places women in a subordinate role to men, and they have lesser rights than men in the patriarchal society. It was expected that Taiwanese women would stay at home and give birth to at least one son (Wang, 2007). Taiwanese women were expected take on the role of caregiver and homemaker, whereas men took on the role of provider of food (Kim, Larochem, \& Tomiuk, 2004). Women often willingly accepted the deprivation of their autonomy and subordinated themselves to men (Wong, 1978; Clark \& Wang, 2004).

Taiwan is no longer such a traditional society, and the role of women in Taiwan has changed. Women in Taiwan now have more access to higher education and careers, which allows them to become more independent and better off financially. They no longer willingly take on a submissive role, nor rely on males to provide for them (Kuo \& Hsu, 2005; Shaw, 2000). However, with more women achieving higher places in society, men with low education and low socioeconomic status (who are also sometimes physically or mentally handicapped) are finding it difficult to get married and start a family (Ting, 2009). Based on Taiwanese tradition, men are responsible for carrying on the family name, so they need to get married and have a son to continue the family bloodline (Chang, 1999). In order to do this, these men have increasingly turned to matchmaking agencies that specialize in finding wives from underdeveloped countries, who are usually not well educated and come from lower socioeconomic classes (Chin \& Yu, 2009; Wang, 2007; Yang \& Wang, 2003).

In the past twenty years, the population of immigrant residents in Taiwan has dramatically increased. According to a report by the Taiwan government information office, there were over 400,000 immigrant residents in Taiwan in 2010, many of whom are women from underdeveloped countries who came to Taiwan to marry. This 
trend began in the 1990s, when international marriages arranged between Taiwanese men and foreign women became more common (Chin \& Yu, 2009). Those women marrying Taiwanese men are referred to as "new immigrants" or "foreign brides." These marriages have transformed the cultural structure of Taiwan (Chin \& Yu, 2009). In 2005, transnational marriages accounted for one in every five marriages, and children of foreign brides accounted for $12.88 \%$ of births (Chin \& Yu, 2009; Government Information Office of Taiwan, 2010). Over the past 10 years, the number of children of foreign brides has increased, and led to the creation of a much more multicultural country than Taiwan has traditionally been. Indeed, according to Ting (2009), one in eight students in primary schools comes from a family composed of a Taiwanese husband and a Southeast Asian wife.

As a result of this demographic change, the children of foreign brides have had to face ethnic tension, racial discrimination, and cultural conflict. The impact of these issues can no longer be ignored. It is necessary to take note of the challenges that children of foreign brides may experience as they grow up in Taiwanese culture.

\section{RISK FACTORS FOR CHILDREN OF FOREIGN BRIDES}

In the United States of American, there are over 100 million non-white citizens, which means that about one in three U.S. residents is a person of color (U.S. Census Bureau, 2002, 2004). The United States is not the only country with multicultural issues. In fact, cultural diversity has become an imperative issue for many countries (Liu \& Kuo, 2007). Traditionally, Taiwan had four major ethnicities: Taiwanese aborigines, Hakka, Taiwanese, and Mainlanders. Today, the Taiwanese government faces a challenge related to demographic changes (Ting, 2009). According to Chen (2007), the impact of foreign brides and the resulting children have led to the necessity of adding a fifth ethnic group to Taiwan. This shift in Taiwanese demographics has led to the children of foreign brides facing a variety of risk factors that may impede their education and sense of self. This study illustrates several of these risk factors and considers how education can help alleviate ethnic tension and provide ethnic-related interventions to children from diverse populations. The risk factors considered are categorized as individual, family, school, and societal.

\section{Individual Risk Factor}

Children of foreign brides have been stereotyped as having slow or poor language development, poor academic performance, and poor interpersonal skills (Chin \& Yu, 2009). Throughout their educational years, these children face this "stereotype threat" (Neville, Tynes, \& Utsey, 2010, p. 212). A negative stereotype puts pressure on the stereotyped population, as they are afraid of strengthening the negative image. For example, African-American students feel threatened when taking exams because they are afraid that their failure would confirm the stereotype that African-American students have less academic skills than their non-African-American peers (Croizet \& Claire, 1998).

\section{Family Risk Factor}

Family is the foundational unit of any society; it plays an important role in maintaining the stability of society. According to Hughes et al. (2009), parenting is a crucial component for the transmission of cultural, ethnic, and group identity for younger generations. If parents fail to transmit cultural, ethnic, and group identity to younger generations, the resulting loss of parental authority and insufficiency of family communication may lead to intergenerational conflicts. Subsequently, this failure negatively impacts children's self-esteem, psychosocial well-being, and academic performance (Gil \& Vega, 1996; Rumbaut, 1996; Zhou, 1997). Having foreign mothers and parents with low education and low socioeconomic status are the family risk factors these children face.

\section{Parents with Low Education/Low Socioeconomic Status}

In 1968, the Taiwanese government implemented a program of compulsory education for nine years for all children. A recent Taiwanese government survey revealed that $71 \%$ of immigrants from Southeast Asia went to school for less than nine years, and only $6.9 \%$ of them obtained a higher education degree (Ministry of Interior, 
2004; Wang, 2007). Further, Wang (2007) reports that among the 82,358 Taiwanese men reporting to have married a foreigner, $81 \%$ of the men are less educated than the average Taiwanese man (Wang, 2007). This suggests that children of foreign mothers will lack educational support from their parents.

\section{The Position of Foreign Brides}

Foreign brides are often at a disadvantage to Taiwanese women because they lack both familial and societal support (Hsieh \& Wang, 2008). They also need to deal with cultural difference (Shu, Lung, \& Chen, 2011). These foreign brides suffer from stereotyping and discrimination as they attempt to assimilate and start a new life in Taiwan. Moreover, because they are seen as having been "bought" by their husbands, they are often treated with little respect. This leads to a sense in the family itself that the mother's culture is inferior, and this can result in an identity crisis for both the mother and her children. Foreign brides also must face a language barrier, and this inability to communicate with Taiwanese people leads to poor interpersonal relationships with Taiwanese natives and this negatively impacts their children's education.

Based on studies by Su (2004) and Ting (2009), the Chinese proficiency and academic performance of children with mothers from Southeast Asia are lower than those of Taiwanese children. Living under the rule of the dominant Taiwanese ethnic group, foreign brides from Southeast Asia are limited in their verbal power and are not encouraged to participate verbally in society. This lack of encouragement leads to less language skill and this, in turn, reinforces the stereotype of foreign brides being less educated and less able than native Taiwanese (Chen \& Chin, 2008). Lin's research (2005) indicates that because language ability in children is influenced by their mothers, children with mothers from Southeast Asia have inferior performances in language development, language comprehension, verbal expression, and interpersonal skills when compared to native Taiwanese children.

Chen and Chin (2008) note that Taiwanese men who marry foreign brides often see them not only as wives but maids. This may add to the lack of support children feel from their mothers (Ting, 2009). Without such support, these children may feel lonely, insecure, and stressed, and have difficulty assimilating into Taiwanese culture (Chin \& Yu, 2009; Shu, Lung, \& Chen, 2011).

\section{School Risk Factor}

School is a place in which children develop and enact their ethnic identities. It is also where children develop their academic orientation and showcase their performance (Hughes, Witherspoon, Rivas-Drake, \& West-Bey, 2009, p.114). As children grow and perceive discrimination in school, there is a decrease in self-esteem. This, in turn, impacts on their academic performance, interpersonal relationships, and general emotional well-being (Parson, 2007; Wei et al., 2008; Yoo \& Lee, 2008).

In the United States, there has been an increase in immigrant children in the classroom over the past twenty years, and racial and/or ethnic differences may be the most important factor to influence students' academic orientation and performance (Kugler, 2009). Racial and/or ethnic differences also play a significant role in Taiwanese schools (Ting, 2009). Culture influences attitudes, manners, and worldviews. It not only influences the way people comprehend their existence and relationships with others and the world, but also the way they interpret the behavior of others (Matsumoto, 1994; Triandis, 1994). Children from diverse backgrounds will thus respond to the world in different ways, which may cause misunderstandings with their school peers (Conoley \& Goldstein, 2004).

In order to decrease the impact of racial and/or ethnic differences on children's academic orientation and performance, teachers should act as facilitators to promote cultural equity and racial harmony (Teel \& Obidah, 2008). The attitudes and beliefs of teachers influence children in several ways. Most importantly, personal attitudes and beliefs have a decisive impact on teachers' expectations of and judgments toward their students' abilities, behaviors, or learning motivation. In other words, pre-existing biases in teachers may hinder their efforts to offer a quality education to all students (Conoley \& Goldstein, 2004). Therefore, teachers should work to eliminate bias or 
stereotyping in their own approaches. Further, in order to act as facilitators to help students appreciate different cultural values, teachers should increase their multicultural awareness, and attempt to create a prejudice-free classroom (Ponterotto, 2006).

\section{Societal Risk Factor}

Evolutionists believe that all animals tend to prefer others who are similar to them, and fear others who are not from the same heredity. Human beings, for example, have a kind of seeking-to-live system in order to protect their own family, group, or race (Buss \& Kenrick, 1998). This in-group favoritism may generate prejudice and stereotypes toward out-groups. This phenomenon can be seen in the Taiwanese job market. Foreign brides are considered to be outsiders, and Taiwanese employers are usually reluctant to hire them. Further, foreign brides who are able to find work in Taiwan are not always treated fairly and equally (Hsieh \& Wang, 2008). Racial biases or stereotypes and unfair job opportunities result from an unconscious tendency by Taiwanese citizens to treat out-group members with distain. The media often reinforces these negative tendencies by presenting foreign brides as having a low status in the social hierarchy of Taiwan. These foreign brides and their children are stereotyped not because what they have done, but who they are (Chen \& Chin, 2008).

\section{INTERVENTIONS}

Interventions are required to eliminate the effects of racism from individuals, families, communities, and nations (Brondolo, et al., 2009). The interventions proposed in this paper concentrate on building up self-efficacy and critical thinking skills in children of foreign brides (Bandura, 1998; Ponterotto, Shawn \& Pedersen, 2006; Walsh, 1988).

From the counselor's perspective, it is important to help people build self-efficacy. Based on Bandura's (1998) social cognitive theory, perceived self-efficacy is based on one's beliefs about capabilities, and ability to reach accomplishments or goals. Self-efficacy affects human functioning through four major psychological processes: cognitive, motivational, affective, and selection processes. People with a strong sense of self-efficacy may know how to think, feel, behave, and motivate themselves to reach their goals and personal well-being. Therefore, those with higher self-efficacy are more likely to be successful because success is positively related to self-esteem. For instance, Sharf's (2008) research shows that African-American students with a high sense of self-efficacy have confidence in their capabilities and competencies. In order to increase children's self-efficacy teachers may use Rose's (2006) asset-based approach to help build a sense of strength and competency.

Another intervention that can be used to deal with racism or discrimination is to foster critical thinking abilities. By focusing on problem-solving, comprehension skills, and ability to extract meaning from situations or environments, critical thinking abilities can help children face, understand, and analyze their thoughts and feelings (Rimiene, 2002). Children who are taught to identify racial tension may use critical thinking skills to discuss racial issues and reach an agreement about how to solve racial issues or problems (Ponterotto, Shawn \& Pedersen, 2006; Walsh, 1988). In order to discuss racism or discrimination issues, teachers may divide children into groups of five or six children and role play scenarios about racism or ethnic tension. Teachers can then facilitate discussion, helping children use their critical thinking skills to learn from the role play and apply it to their real lives.

Aside from developing self-efficacy and critical thinking skills, immigrant children may also be educated by using individual-level coping strategies - racial identity development, social support seeking, and anger suppression and expression - that Brondolo et al. (2009) identify as three major stress buffers to deal with racism and ethnic tension.

Racial identity can be defined as one's attitude toward, awareness of, and knowledge about one's own position in relation to the majority racial group (Neville, Tynes \& Utsey, 2010). An individual recognizes, through verbal or nonverbal behaviors acting upon them, whether they are an in-group or out-group member (Brondolo et al., 2009). The conscious development of racial identity can protect children from falling into depression or losing 
self-esteem, as it highlights the fact that negative evaluation comes from ethnic stereotyping and not from an individual's personal characteristics (Harris-Britt, Valrie, Kurtz-Costes, \& Rowley, 2007; Mossakowski, 2003). People with strong racial identities are less moody and have good self-esteem. Further, belonging to and feeling pride in belonging to a certain racial group is considered a means to moderate the relationship between discrimination and self-esteem (Brondolo et al., 2009; Harris-Britt, Valrie, Kurtz-Costes, \& Rowley, 2007). The sense of pride of belonging to a certain group also allows children of immigrants to have a chance to seek social support from their cultural group, including communicating with or getting help from those self-identifying as in-group members (Brondolo et al., 2009).

The ability to seek social support from one's in-group also has a positive effect on physical and psychological health (Brondolo et al., 2009; Noh \& Kaspar, 2003; Yoo \& Lee, 2005). As Krieger (1990) notes, the majority of black people feel they are able to lean on one another, and talk and seek advice about racial discrimination. By helping children of foreign brides participate in social support-seeking activities, teachers can help them increase their sense of group cohesion and decrease levels of anger and frustration arising from racism or ethnic tension. Foreign brides can also help their children set up strong support systems in which children may find positive role models. Anger suppression and expression techniques can serve as another option for dealing with ethnic tension and racial stereotyping. Using the copying strategy of anger suppression and expression, children may find a way to deal with racial conflicts and ethnic tension and know how to manage emotional barriers (Brondolo $e t$ al., 2009; Stevenson, 2003). These interventions and coping strategies may be used to help children of foreign brides in Taiwan to lessen ethnic tensions and racial discrimination and conflict.

\section{CONCLUSION}

Lewis (2004) writes, "The past, if not forgotten, can serve as a guide for the future" (p. 629). Racial power influences the lives of everyone; it determines how people live and interact with one another. Racial stereotyping and discrimination comes from mistrusting and misunderstanding different racial groups. The gap between Taiwanese and immigrants, especially foreign brides and their children, results in culture estrangement and alienation. Native-born Taiwanese have ethnic privilege and dominance, and are able to impose their rules on other ethnic groups. Abuse of this power can cause pain to members of other groups. This study considered how culture acts upon the children of foreign brides, and suggested that these children encounter challenges on individual, family, school, and societal levels that may impede their education and sense of self. The study illustrates the risk factors and how education can deal with ethnic tension appropriately by providing interventions. Through the development of self-efficacy and critical thinking skills, and through the use of individual coping strategies, including racial identity development, social support seeking, and anger suppression and expression, teachers can help children of foreign brides learn to deal appropriately with racial conflicts and tensions. Through these techniques they can help eliminate the effects of racism, from individuals, families, communities, and nations, but most importantly, they can bring about positive academic and behavioral outcomes to children at an individual level.

\section{AUTHOR INFORMATION}

Pei-Chun Liao, Department of Applied Psychology-Human Development Division, University of Pennsylvania, USA.

Ya-huei Wang, Ph.D., is an Associate Professor at Chung-Shan Medical University. She received her master degree in English literature from University of Rochester, U.S.A. and her Ph.D. in education from National Changhwa University of Education, Taiwan. Her research interests include applying effective motivational strategies and learning strategies to English language and literature instruction, extensive reading, and medical humanities. Her papers have been published by Expert Systems with Applications, the British Journal of Educational Technology, the Journal of Management in Education, the Asian EFL Journal Quarterly, the European Journal of Social Science, etc. E-mail: yhuei@csmu.edu.tw (Corresponding author) 


\section{REFERENCES}

1. Bandura, A. (1994). Self-efficacy. In V. S. Ramachaudran (Ed.), Encyclopedia of human behavior (Vol. 4, pp 71-81). New York: Academic Press. (Reprinted in H. Friedman [Ed.], Encyclopedia of mental health. San Diego: Academic Press, 1998.

2. $\quad$ Brondolo, E., Brady, N., Pencille, M., Beatty, D., \& Contrada, R. J. (2009). Coping with racism: A selective review of the literature and a theoretical and methodological critique. Journal of Behavioral Medicine, 32. doi:10.1007/s10865-008-9193-0.

3. Buss, D. M., \& Kenrick, D. T. (1998). Evolutionary social psychology. In D. Gilbert, S. Fiske, \& G. Lindzey (Eds.), The handbook of social psychology (4 ${ }^{\text {th }}$ ed., Vol. 2, pp.982-1026). New York: Random House.

4. Chang, G. G. (1999). The family function of foreign brides in the south of Taiwan. National Science Council, Taipei.

5. Chen, T. M. (2007). The Research of New Immigrant of Care Policy in Taiwan's Nonprofit Organization. Retrieved from http://www.ftope.org.tw/web/pdf/403.pdf

6. Chen, Y. N., \& Chin, M. H. (2008). The Role Replaced: Unmarried Taiwanese Women and the Foreign Brides. UC Los Angeles: UCLA Center for the Study of Women.

7. Chin, J. \& Yu, S. (2009). School adjustment among children of immigrant mothers in Taiwan. Social Behavior and Personality, 36(8), 1141-1150.

8. Clark, K. J., \& Wang, R. R. (2004). A Confucian defense of gender equity. Journal of the American Academy of Religion, 72(2), 395-422.

9. Conoley, J. C., \& Goldstein, A. P. (2004). School violence intervention (2nd ed). New York, NY: The Guilford Press.

10. Croizet, J. C., \& Claire, T. (1998). Extending the concept of stereotype threat to social class: The intellectual underperformance of students from low socioeconomic backgrounds. Personality and Social Psychology Bulletin, 24(6), 588-594.

11. Gil, A.G., \& Vega, W.A. (1996). Two different worlds: Acculturation stress and adaptation among Cuban and Nicaraguan families in Miami. Journal of Social and Personal Relations, 13, 437-458.

12. Government Information Office of Taiwan. (2010). 2010 Taiwan Year Book. Retrieved from http://www.gio.gov.tw/taiwan-website/5-gp/yearbook/

13. Harris-Britt A., Valrie, C. R., Kurtz-Costes B., \& Rowley, S. J. (2007). Perceived racial discrimination and self-esteem in African American youth: racial socialization as a protective factor. Journal of Adolescent Research, 17(4), 669-682.

14. Hsieh, C. Y., \& Wang, C. Y. (2008). Immigrant wives and their cultural influence in Taiwan. Journal of National Taiwan Normal University, 53(2), 101-118.

15. Hughes, D., Witherspoon, D., Rivas-Drake, D., \& West-Bey, N. (2009). Received ethnic-racial socialization messages and youths' academic and behavioral outcomes: examining the mediating role of ethnic identity and self-esteem. Cultural Diversity and Ethnic Minority Psychology, 15, 2, 112-124.

16. Kim, C., Laroche, M., \& Tomiuk, M. (2004). The Chinese in Canada: A study in Ethnic change with emphasis on gender roles. The Journal of Social Psychology, 144(1), 5-29.

17. Krieger, N. (1990). Racial and gender discrimination: Risk factors for high blood pressure? Social Science and Medicine, 30(12), 1273-1281.

18. Kugler, E.G. (2009). Partnership with parents and families to support immigrant and refugee children at school. Center for Health and Health Care in Schools, School of Public Health and Health Services, the George Washington University, Washington, DC. Retrieved from http://healthinschools.org/Immigrantandrefugeechildren.aspX

19. Kuo, Y., \& Hsu, Y. T. (2005). Implementation evaluation on foreign brides literacy education in Taipei. Paper presented at the When Women Gain, So Does the World, IWPR's Eighth International Women's Policy Research Conference.

20. Lewis, A. E. (2004). "What Group?" Studying whites and whiteness in the era of "color-blindness." Sociological Theory, 22(4), 623-646. 
21. Lin, H. Y. (2005). Dong nan ya xin zhu min mu qin di wu sui you er guo yu neng li zhi yan jiu [The study on the mandarin knowledge of 5-years-old new inhabitants' children whose mothers from Southeast Asia]. Unpublished dissertation, National Taipei University of Education, Taipei.

22. Liu, K., \& Kuo, L. T. W. (2007). Cultivating aboriginal cultures and educating aboriginal children in Taiwan. Childhood Education, 83(5), 282-287.

23. Matsumoto, D. (1994). People: Psychology from a cultural perspective. Prospect Heights, IL: Waveland Press.

24. Ministry of Interior (2004). Survey on Living Conditions of Foreign and Mainland Chinese Spouses. Taipei: Ministry of Interior Affairs.

25. Mossakowski, K. N. (2003). Coping with perceived discrimination: Does ethnic identity protect mental health? Journal of Health and Social Behavior, 44(3), 318-331.

26. Neville, H. A., Tynes, B. M., \& Utsey, S. O. (2010). Handbook of African American Psychology. Thousand Oaks, CA.

27. Noh, S., \& Kaspar, V. (2003). Perceived discrimination and depression: Moderating effects of Coping, acculturation, and ethnic support. American Journal of Public Health, 93(2), 232-238.

28. Ponterotto, J.G., Shawn, O.U., \& Pedersen, P.B. (2006). Preventing prejudice: A guide for counselors, educators, and parents ( $2^{\text {nd }}$ ed.). Thousand Oaks, CA: Sage.

29. Rimiene, V. (2002). Assessing and developing student's critical thinking. Psychology Learning and Teaching, 2(1), 17-22.

30. Rose, H. A. (2006). Asset-based development for child and youth care. Reclaiming Children and Youth, 14(4), 236-240.

31. Rumbaut, R. G. (2004). Ages, life stages, and generational cohorts: decomposing the immigrant first and second generations in the United States. International Migration Review, 38, 3, 1160-1205.

32. Sharf, R. S. (2008). Behavior Therapy. Theories of psychotherapy and counseling: Concepts and cases $\left(4^{\text {th }}\right.$ ed). California: Brooks/Cole.

33. Shaw. P. (2000). Changes in female roles in Taiwanese women's magazines, 1970-1994. Media History, 6, 2. Retrieved from http://icm.cm.nsysu.edu.tw/teacher/Media\%20History(2000).pdf

34. Shu, B. C., Lung, F. W., \& Chen, C. H. (2011). Mental health of female foreign spouses in transnational marriages in southern Taiwan. BMC Psychiatry, 11:4. doi:10.1186/1471-244X-11-4 Retrieved from http://www.biomedcentral.com/1471-244X/11/4.

35. Stevenson, Jr., H. C. (2003). Playing with anger: Teaching coping skills to African American boys through athletics and culture. Westport, CT.: Greenwood Publishing, Praeger.

36. Su, H. (2004). Tai wen zhong quo yu dong nan ya xin niang zhi zi nu di guo yu wen neng li yu xue ye biao xian [The language ability and academic performance of the children of Taiwanese, Chinese and Other Asian brides in Taiwan]. Unpublished dissertation, Leader University, Tainan.

37. Teel, K. M. \& Obidah, J. E. (2008) Building Racial and Cultural Competence in the Classroom. New York, New York: Teachers College, Columbia University.

38. Ting, C. W. (2009). Taiwanese preschool teachers' awareness of cultural diversity of new immigrant children: implications for practice. Unpublished doctoral dissertation, University of North Texas.

39. Triandis, H. C. (1994). Culture and social behavior. New York: McGraw-Hill.

40. U.S. Census Bureau. (2002). The Asian population: 2000. Census 2000 brief. Retrieved from http://www.cdc.gove/omhd/populations/AsianAm.htm/

41. U.S. Census Bureau. (2004). U.S. interim projections by age, sex, race, and Hispanic origin. Retrieved from http://www.census.gov/ipc/www/usinterimproj/

42. Walsh, D. (1988). Critical thinking to reduce prejudice. Social Education, 52, 280-282.

43. Wang, H. Z. (2007). Hidden spaces of resistance of the subordinated: Case studies from Vietnamese female migrant partners in Taiwan. International Migration Review, 41(3), 706-727.

44. Wei, M., Ku, T. Y., Russell, D. W., Mallinckrodt, B., \& Liao, Y.H. (2008). Moderating effects of three coping strategies and self-esteem on perceived discrimination and depressive symptoms: A minority stress model for Asian international students. Journal of Counseling Psychology, 55, 4, 451-462.

doi:10.1037/a0012511. 
45. Wong, A. K. (1978). The modern Chinese family. In M. S. Das \& P. D. Bardis (Eds.), The family in Asia. New Delhi, India: Vikas.

46. Yang, Y. M., \& Wang, H. H. (2003). Life and health concerns of Indonesian women in transnational marriages in Taiwan. Journal of Nursing Research, 11(3), 167-176.

47. Yoo, H. C., \& Lee, R. M. (2005). Ethnic identity and approach-type coping as moderators of the racial discrimination/well-being relation in Asian Americans. Journal of Counseling Psychology, 52(4), 497-506.

48. Yoo, H. C., \& Lee, R. M. (2008). Does ethnic identity buffer or exacerbate the effects of frequent racial discrimination on situational well-being of Asian Americans? Journal of Counseling Psychology, 55, 1, 63-74. doi:10.1037/0022-0167.55.1.63.

49. Zhou, M. (1997). Growing up American: The challenge confronting immigrant children and children of immigrants. Annual Review of Sociology, 23, 63-95. 